образовательном процессе может позволить китайским обучающимся в определенной степени понять культурные различия между двумя странами, чтобы лучше адаптироваться к русскоязычной культурной среде, тем самым снизив вероятность возникновения межкультурных барьеров в общении.

1. Хун Чжао, Факторы времени и пространства в межкультурной коммуникации Китая и России. Шанхайский международный университет исследований, 2010. - С.8 - 28.

2. Hall Edward, translated by Liu Jianrong, "Silent Language" Shanghai People's Publishing House, 1991. p. 152

3. Han Yinyan, Qian Xin, A Comparison of the Differences between Chinese and Western Time Concepts in Cross-cultural Communication, Journal of Liaoning Normal University, Vol.29 No.4 Jul. 2006. - p. 16.

4. Wen Li, Comparison of Chinese and Western Time Concepts, [Электронный ресурс] https://m.xzbu.com/9/view-988143.htm

5. Pan Guoqiang, One-Way System and Multi-Way Time System: Differences in Time Concepts Between Chinese and Western Cultures, Journal of Zhejiang Transportation College ,Vol.7 No.3 Sep. 2006. - pp. $61-63$.

6. Ashley C. Fulmer, Brandon Crosby and Michele J. Gelfand, Cross-Cultural Perspectives on Time, Psychological Press, 03.2014. - pp. 6 - 14

7. Bi Jiwan, "Cross-Cultural Nonverbal Communication" Foreign Language Teaching and Research Press, 1999. - p. 73

8. Sang Zhi, On the privacy rights of Chinese citizens, Bengbu Channel of China Court Network, 16.09.2010. [Электронный ресурс] https://www.chinacourt.org/article/detail/2010/09/id/427840

9. Yu Yi-da, Partner Program: cultivating intercultural communicative competence in native context, Journal of Jiamusi Vocational College No.1. Sum 170 2017. - pp.343 - 345.

\title{
Чимаров С.Ю., Алексеев А.А. \\ Историко-педагогические аспекты формирования широты эрудиции начальствующего состава ОВД России: в контексте опыта спартанской и афинской школ воспитания
}

Санкт-Петербургский университет МВД России (Россия, Санкт-Петербург)

doi: 10.18411/lj-04-2021-180

\section{Аннотация}

В статье представлен анализ основных положений спартанской и афинской систем воспитания, предопределивших формирование многих последующих научных школ, ориентированных на подготовку гармонично развитого человека в духе гражданственности и пользы своему Отечеству. Акцентируя внимание на важности учета отмеченного опыта, авторы утверждают о важности изучения истории педагогики начальствующим составом органов внутренних дел в решении задач как развития широты своей эрудиции, так и воспитания подчиненных с позиций системности данного вида педагогического воздействия и высокой требовательности за исполнение долга службы.

Ключевые слова: педагогическая мысль, история педагогики, система воспитания, античный период, традиции, широта эрудиции, органы внутренних дел.

\section{Abstract}

The article presents an analysis of the main provisions of the Spartan and Athenian educational systems, which predetermined the formation of many subsequent scientific schools, focused on the preparation of a harmoniously developed person in the spirit of citizenship and benefit to his Fatherland. Focusing on the importance of taking into account the experience noted, the authors argue about the importance of studying the history of pedagogy by the commanding staff of internal affairs bodies in solving the problems of both developing the breadth of their erudition and educating subordinates from the standpoint of 
the systematic nature of this type of pedagogical influence and high exactingness for the performance of duty.

Keywords: pedagogical thought, history of pedagogy, education system, antique period, traditions, breadth of erudition, internal affairs bodies.

История педагогической мысли оставила скудные сведения о системе воспитания в доклассовом обществе Древней Греции. В дошедших до нашего времени исторических документах и в специальной литературе по истории педагогике наиболее обстоятельно представлен опыт воспитания в древне-греческом обществе на примерах Спарты и Афин (VI-IV вв. до н.э.), система воспитания в которых может быть оценена в качестве эталона для античной Греции. Изучение данного опыта обеспечивает адаптацию старых импульсов эпохи исчезнувших поколений к новым условиям переживаемого человеком времени, а также сохраняет преемственность ритуалов поведения человека и способствует укреплению традиций социального взаимодействия $[5$, c. 60$]$;

Нам представляется небезынтересным и несомненно актуальным апеллирование к наследию данного опыта в целях формирования профессионального мировоззрения личности руководителя органов внутренних дел (далее-ОВД), обеспечения широты его эрудиции и вооружения научно-педагогического состава системы МВД России соответствующего рода систематизированными сведениями. Отмеченный тезис корреспондирует положениям ч. 4 ст. 16 Кодекса профессиональной этики сотрудника органов внутренних дел Российской Федерации», введенного в действие Приказом МВД РФ от 24 декабря 2008, в соответствии с которыми «культура профессионального поведения руководителя определяется степенью развития его интеллекта, широтой эрудиции, обширностью интересов, уровнем образованности и воспитанности». Несмотря на то, что сейчас действует новый Кодекс поведения, мы считает указанные положения Кодекса 2008 г. по-прежнему актуальными.

I. Bocnumaнue в Cnapme. Античное государство Спарта или Лакедемон (XI в. до н.э.-146 г. до н.э.) располагалось в области Лакония на территории полуострова Пелопоннес. Доминантой воспитания спартанцев выступало привитие им чувств выносливости, мужества, беспрекословности послушания, что способствовало поддержанию в них духа воинственности и постоянной готовности как к подавлению вооруженным путем восстаний порабощенного местного населения, превращенного в государственных рабов - «илотов», так и к защите своего суверенитета от внешней агрессии, а также обеспечения первенствующего положения среди других народов Древней Греции. Как отмечают Ш.И. Ганелин и Е.Я. Голант, «сохранившиеся сведения рисуют чрезвычайно яркую картину воспитания у спартиатов, рассчитанного на подготовку воинов. Детей, родившихся слабыми, по решению старейшин, кидали в пропасть. До 7 лет дети находились дома. С 7 до 18 лет они жили и воспитывались в государственных учреждениях» [2, с. 11]. В арсенал спартанских средств воспитания входило: а) привитие навыков выживания в условиях холода, голода и терпения к физической боли (посредством умеренного кормления, ношения легкой одежды, отдыха/сна на жесткой постели из тростника, жестокой порки); б) развитие военной хитрости и ловкости (посредством специальных занятий и поощрения воровства продуктов питания или овощей и фруктов, с последующим жестоким наказанием тех, кто был обнаружен в совершении указанного действия); в) организация военногимнастической подготовки (посредством обучения бегу, прыжкам, метанию диска и копья, приемам борьбы и рукопашного боя); г) обучение только основам письма и чтения, включая обучение декларированию стихов о военной доблести; д) обучение музыке, преимущественно военной. Вся система спартанской подготовки основывалась на строгой дисциплине. С 18 до 20 лет спартанские юноши относились к категории «эфебыl»: после первого года службы совершалась процедура вручения от государства 
каждому юноше щита и копья, с одновременным его приведением к тексту клятвы (аналогу современной присяге) [3, с. 246]. Период нахождения молодых людей в эфебах был посвящен исключительно их военной подготовке, а после достижения ими курса указанной подготовки спартанец вступал в войско.

Отличительной особенностью воспитания являлось привитие обучающимся умения четко и кратко выражать свои мысли. В настоящее время указанный способ именуется в качестве «лаконичного»: корень данного слова происходит от наименования местонахождения Спарты - области Лакония. В качестве примера лаконичности спартанцев можно привести хрестоматийный пример, сопряженный с высказыванием спартанского царя Леонида (491-480 гг. до н.э.) в период битвы при Фермопилах (480 г. до н.э.), который в ответ на витиеватое предложение персидского царя Ксеркса I (486-465 гг. до н.э.) сложить оружие в обмен на жизнь лаконично суть кратко ответил «Приди и возьми».

II. Bоспитание в Афинах. Древнегреческий полис Афины имел статус города-государства (VIII в. до н.э.- 146 г. до н.э.), расположенного на территории области Аттика. Существенным образом отличаясь от Спарты по своему общественному строю и уровню развития культуры, Афинское государство имело совершенно иную систему воспитания и образования, что предопределялось воздействием древнегреческой философской мысли. По утверждению Ф. Энгельса, «В многообразных формах греческой философии уже имеются в зародыше, в процессе возникновения, почти все позднейшие типы мировоззрений» [6, с. 369]. Важное значение для педагогического процесса вообще и системы воспитания в частности имеет проведенная Аристотелем (384-322 гг. до н.э.) античная возрастная периодизация воспитания человека: а) от рождения до 7 лет (дошкольный возраст): детские игры и рассказ сказок; б) с 7 до 14 лет (школьный возраст): мусическое (литературное и музыкальное) воспитание (у грамматиста и кифариста), обучение грамоте, чтению, письму, счету, гимнастические занятия; в) с 14 лет до 21 года (юношеский возраст): усиленное гимнастическое воспитание (прыжки, бег, метание диска и копья, рукопашный бой, плавание, иногда охота, беседы на философские и политические темы[1-5, с. 250]. Следует заметить, что афинская школа было платной и учитель «дидаскал» получал от родителей высокую плату за свои труды. Младших детей в школу сопровождало специальное лицо, именуемое «педагог» суть «водитель детей». Как правило это был раб, в миссию которого наряду с сопровождением ребенка входили обязанности надзора за его поведением дома и во время учебных занятий. С 18 до 20 лет афинские юноши также, как и спартанские входили в группу «эфебов»: в это время они занимались не только военной подготовкой, но и изучением гражданских законов. Молодые люди из числа эфебов, получая в руки оружие, перед алтарем афинской священной башни Аграулос принимали клятву, текст которой приводит французский историк педагогики Ш. Летурно: «Клянусь не обесчестить этого оружия н никогда не покидать в битве товарища. Я буду сражаться за храмы богов и за общее благо, один или с товарищами. Я не оставлю Отечество уменьшенным, но более обширным и более сильным. Я буду слушаться тех, кто при каких бы то ни было обстоятельствах судит справедливо. Я буду повиноваться существующим законам, равно как и тем, которые примет народ. Если кто-либо возмутится против законов и откажется подчиняться им, я буду их защищать, один или вместе с другими. Я буду чтить национальных богов и святилища. Беру в свидетели божества Аграулос, Эниалия, Ареса, Зевса, Талло, Ауксо. Гегемону» [4, с. 360-361].

Особого внимания заслуживает тот факт, что в воспитательной работе с афинянами важное значение уделялось развитию у граждан чувств собственного достоинства, самообладания, душевного спокойствия, приятных манер и почтительного отношения к старшим. 
Резюмируя изложенное, мы приходим к выводам: во-первых, о сформированности в указанных античных государствах системы воспитательной работы, ориентированной на запрос общества и потребности времени; во-вторых, знание начальствующим составом ОВД сущностных основ становления античной системы воспитания в духе гражданственности и готовности к защите своего Отечества способствует как широте эрудиции данной категории сотрудников ОВД, так и позволит укрепить их уверенность в важности системной и целенаправленной работы с каждым подчиненным сотрудником по формированию у него профессиональных и общегражданских качеств.

\section{$* * *$}

1. Аристотель. Сочинения: в 4-х т. Т. 4 / Пер. с древнегреч.; общ. ред. А. И. Доватура. М., 1983. - 832 c.

2. Ганелин Ш.И., Голант Е.Я. История педагогики. - М.: Государственное учебно-педагогическое издательство Наркомпроса РСФСР, 1940. - 608 с.

3. Латышев В.В. Очерк греческих древностей. В двух частях. Ч. 1. Государственные и военные древности. - СПб.: Изд-во Алеейя, 1997. - 348 с.

4. Летурно Ш. Эволюция воспитания у различных человеческих рас. - СПб.: Типография «Грамотность», 1907. - 498 с.

5. Чимаров С.Ю. Концептуальные основы происхождения воспитания в формате эволюции разума и нравственности: история педагогики // Тенденции развития науки и образования. - 2021. - № 69. Часть 5. - С. 58-61.

6. Энгельс Ф. Диалектика природы / Маркс К., Энгельс Ф. Сочинения. Издание второе. Том 20. - М.: Государственное издательство политической литературы, 1961. -828 с.

\section{Nurutdinova A.R. \\ A new educational paradigm: the formation of a didactically competent multicultural and multilingual personality (linguamultimedia competence of a foreign language teacher)}

Kazan (Volga Region) Federal University (Russia, Kazan)

doi: 10.18411/lj-04-2021-181

\section{Аннотация}

Глобальные политические, экономические и социальные изменения в стране, а также укрепление межэтнических и международных контактов интеграционные процессы в полиэтническом обществе обусловили появление новой образовательной парадигмы, где базовым требованием является переход от интуитивных и технократических дисциплин, накопления знаний и навыков к повышению индивидуального и социального интеллекта, от классической и «открытой» триады «знание - навыки - способности» к замкнутому циклу «знания - навыки - умения акцентуализация (применение, технология)» т.е. производство и развитие компетенций, но приоритетом выступает коммуникация. Такая интерпретация новой образовательной парадигмы привела к необходимости более тщательного изучения коммуникативных процессов, включая межкультурное общение в целом и преподавание иностранных языков в частности. Информатизация общества рассматривается не только как технологический феномен, но и как феномен современной культуры. Таким образом, лингвомультимедийная компетентность как информационная среда современной мультикультурной лингвистической реальности т.е. новая технологическая реальность.

Ключевые слова: парадигма образования, межкультурная коммуникация, цифровой лингво-мультимедийный контекст, лингво-мультимедийная компетенция, мультикультурность и многоязычность, мультимедийно-опосредованная межкультурная коммуникация. 